J. Asiat. Soc. Bangladesh, Sci. 39(2): 129-138, December 2013

\title{
ASSESSMENT OF FOUR DIFFERENT MEDIA FOR THE MASS CULTURE OF CERIODAPHNIA RETICULATA (JURINE) AS A LIVE FISH FEED
}

\author{
M. BEGUM ${ }^{1}$, P. NOOR, K. N. AHMED, L. C. MOHANTA, N. SULTANA, \\ M. R. HASAN AND M. N. UDDIN ${ }^{2}$ \\ Zoology Section, Biological Research Division, BCSIR Laboratories Dhaka, Dhaka-1205 \\ ${ }^{2}$ Pulps and Paper Research Division, BCSIR Laboratories Dhaka, Dhaka-1205
}

\begin{abstract}
Experiments on the mass culture of Ceriodaphnia reticulata (Jurine) were carried out in aquarium water for 54 days with different media like cowdung $(1.5 \mathrm{~g} / \mathrm{L})$, pulse bran water $(50 \mathrm{~g} / \mathrm{L})$, poultry manure $(0.45 \mathrm{~g} / \mathrm{L})$ and snail faeces (faeces of six apple snails). All the media were fertilized by $50-100 \%$ of the initial amount of feed in every 7 days. About 100 individuals of $C$. reticulata were inoculated as starter in 50 litres of water (2 individuals $/ \mathrm{ml}$ ). The temperature of the media ranged from $24-30^{\circ} \mathrm{C}$ during study period. $\mathrm{p}^{\mathrm{H}}$ of the culture media varied i.e., $9.1 \pm 0.40$ in cowdung; $8.72 \pm 0.73$ in pulse bran water, $8.82 \pm 0.72$ in poultry manure and $7.5 \pm 0.55$ in snail faeces. The highest average population of $C$. reticulata was observed in cowdung $(8.56 \pm 4.11$ individuals $/ \mathrm{ml})$, moderate in poultry manure $(4.21 \pm 2.97$ individuals $/ \mathrm{ml})$ and snail faeces $(2.52 \pm$ 3.01 individuals $/ \mathrm{ml})$. The lowest growth of $C$. reticulata was recorded in pulse water $(0.37$ \pm 0.69 individuals $/ \mathrm{ml}$ ). The culture media with cowdung as well as poultry manure and snail faeces were found to be useful for artificial mass production of C. reticulata.
\end{abstract}

Key words: Assessment, Food media, Mass culture, Live fish feed, Ceriodaphnia reticulata

\section{Introduction}

Zooplanktons are important food item for the young and some adults of many freshwater fishes which represent a major component of the human diet (Kenneth 1990). Among freshwater zooplankton, rotifers, cladocerans and copepods are dominant groups throughout the year (Hutchinson 1967). Successful hatchery production of the fish fry and crustaceans for aquaculture depends on the availability of zooplankton of appropriate size of larval feeding. Freshly hatched Artemia nauplii has been popular larval feed used by the scientists and aquaculturists for a long time. But the high cost of Artemia cysts has led to the aquaculturists to search for alternative suitable zooplankton which could be easily reared in large scale. The rotifer Brachionus plicatilis, the cladoceran, Moina sp, the harpacticoid copepods such as Tigriopus spp and Tispe spp., nematodes, Panagrellus spp. and the ciliate Fabrea salina all of which have high reproductive rate, short generation time and the ability to live and grow in crowded culture conditions that are found to be useful as live feed for larval rearing of cultivable species of fish and crustaceans (Muthu 1982).

${ }^{1}$ Corresponding author: Email: panna_mahmuda@yahoo.com 
Zooplankton play an important food item of omnivorous and carnivorous fishes (Alam et al.1987). Cladocerans often known as 'water fleas' because of their shape and "hop-sink" type of locomotion are the major group of zooplankton available in freshwater ponds. Larger fry and even adults of some fish species often selectively prey on the crustaceans (Ludwig 1999). Ceriodaphnia is a small cladoceran genus that has higher protein content than Daphnia and is an excellent feed for fish fry with minute mouths. The males range from $0.4-0.8 \mathrm{~mm}$ in length, whereas the size of females is $0.4 \mathrm{~mm}$ to $1.4 \mathrm{~mm}$ in length that varied depending upon various species (Balcer et al. 1984).

In the study, Ceriodaphnia reticulata, an important cladoceran as fish food had been selected for mass culture in aquaria with different types of media. Development of a suitable culture media for commercial production of Ceriodaphnia sp. will be an inexpensive alternative approach to live feeds needed for fish rearing.

\section{Materials and Methods}

The experiments were conducted over a period of 54 days in the Zoology Section of BCSIR Laboratories, Dhaka. Ceriodaphnia reticulata was collected from local water bodies of Dhaka city and this species was identified according to Brooks 1959. The culture media maintained in 12 aquarium tanks of $75 \mathrm{~cm} \times 36 \mathrm{~cm} \times 36 \mathrm{~cm}$ size with aeration for $24 \mathrm{hrs}$. Each tank was washed, left to dry and then filled with 30 litres of tap water. The tap water was kept for two days for seasoning. On the 3rd day, the tanks were fertilized by four different types of food media with three replicates for each treatment. The media were cowdung (44.88g dried manure +30 litres of water) (Rottman 1992), pulse bran water with Chlorella $(1.5 \mathrm{~g}$ Urea $+0.3 \mathrm{~g}$ TSP $+3 \mathrm{~g}$ salt $+600 \mathrm{ml}$ pulse bran water $+100 \mathrm{ml}$ Chlorella +30 litres of water), poultry manure (13.45g dried manure +30 litres of water) and snail faeces (six apple snails feed on 2-3 cabbage leaf daily). Additional feed, approximately $50-100 \%$ of the initial amount were added to 5 days later. On the third day of the experiment, about 100 individuals of C. reticulata were introduced to the culture medium of each tank as starter. Following initiation of different growth experiments, the number of living individuals of each tank was counted daily. These processes continued until population study in each replication that started to decline. The population of $C$. reticulata was recorded by using the Sedgewick-Rafter counter cell which is $50 \mathrm{~mm}$ long, $20 \mathrm{~mm}$ wide and $1 \mathrm{~mm}$ deep. Zooplankton number (no./ml) was calculated according to the formula outlined by Boyd and Lichktoppler (1979):

Number of zooplankton $/ \mathrm{ml}=\underline{\mathrm{T} \times 1000}$

A x $\mathrm{N} \times$ Vol. of concentrate in $\mathrm{ml} / \mathrm{Vol}$. of sample

Where, $\mathrm{T}=$ total number of zooplankton counted

$\mathrm{A}=$ area of grid in $\mathrm{mm}^{2}$

$\mathrm{D}=$ Number of grids counted

$1000=$ area of counting chambers in $\mathrm{mm}^{2}$ 
Water temperature $\left({ }^{\circ} \mathrm{C}\right)$ of the culture media were recorded by using a mercury thermometer and $\mathrm{pH}$ was detected with the help of a portable $\mathrm{pH}$ meter (model-HI 98103) before sampling started at 10.00 a.m. once in every 3 days. The statistical analysis of different physico-chemical parameters were carried out by using one-way ANOVA and any difference at $5 \%$ level of significance by using the statistical package of SPSS16(SYSTA, USA) to express the results.

\section{Results and Discussion}

Media, $\mathrm{pH}$ level and water temperature, affect the growth and reproduction of Ceriodaphnia. The growth of Ceriodaphnia reticulata varied from medium to medium used in this experiment (Fig. 1). Among the media, the highest average number of individuals were recorded in cowdung medium of $8.56 \pm 4.11 \mathrm{no} . / \mathrm{ml}$ whereas $C$. reticulata reared on pulse bran water medium exhibited the lowest density of $0.37 \pm 0.69$ no. $/ \mathrm{ml}$. The other cultured media like poultry manure and snail faeces showed moderate population growth of $4.21 \pm 2.97$ and $2.52 \pm 3.01 \mathrm{no} . / \mathrm{ml}$ respectively on an average (Table 1).

Table 1. Average $\mathrm{pH}$, temperature, survival and number of individuals of four different culture media.

\begin{tabular}{l|l|l|l|l}
\hline Feeds & $\begin{array}{l}\mathrm{pH}(\text { Mean } \pm \\
\text { SD) }\end{array}$ & $\begin{array}{l}\text { Temperature } \\
\left({ }^{\circ} \mathrm{C}\right)\end{array}$ & Days of survival & $\begin{array}{l}\text { Number } \\
\text { Individuals } \\
(\text { Mean } \pm \text { SD) }\end{array}$ \\
\hline Cowdung & $* 9.1 \pm 0.40^{\mathrm{a}}$ & $26.28 \pm 1.88^{\mathrm{c}}$ & $29.08 \pm 15.29^{\mathrm{a}}$ & $8.56 \pm 4.11^{\mathrm{a}}$ \\
Poultry manure & $8.82 \pm 0.72^{\mathrm{b}}$ & $27.52 \pm 1.42^{\mathrm{b}}$ & $25.21 \pm 16.94^{\mathrm{b}}$ & $4.21 \pm 2.97^{\mathrm{b}}$ \\
Pulse bran & $8.72 \pm 0.73^{\mathrm{b}}$ & $26.42 \pm 1.67^{\mathrm{bc}}$ & $26.22 \pm 15.46^{\mathrm{ab}}$ & $0.37 \pm 0.69^{\mathrm{d}}$ \\
water & & & \\
Snail faeces & $7.5 \pm 0.55^{\mathrm{c}}$ & $30.41 \pm 0.88^{\mathrm{a}}$ & $27.43 \pm 16.94^{\mathrm{ab}}$ & $2.52 \pm 3.01^{\mathrm{c}}$ \\
\hline
\end{tabular}

*means containing the same letters do not differ significantly at $5 \%$ level of significance.

Effects of days of survival: The parameter on the days of survival was studied to make a comparison of the effects of cultured food media in cultivation of C. reticulata. At the end of 54 days of experiment, average days of survival were highest in cowdung media $(29.08 \pm 15.29)$ and lowest in poultry manure media $(25.21 \pm 16.94)$.

There was a significant $(\mathrm{p}<0.01)$ relationship between the number of individuals and days of survival $(r=0.441)$ and that the number of organisms increased with time in cowdung medium. The effects of days of survival on the growth of individual cultured in four types of media were not the same (Fig. 2). In cowdung, the population of $C$. reticulata showed more or less average growth rate over the period with two peaks abundances on the $15^{\text {th }}$ and the $40^{\text {th }}$ day. There was no figure for complete decline of this organism in cowdung medium. In poultry manure, the population started to grow from first day to fourth day and became steady till $10^{\text {th }}$ day. It grew upto 6 individual $/ \mathrm{ml}$ in 
similar fashion till $23^{\text {rd }}$ day and then suddenly increased to 10 individual $/ \mathrm{ml}$ by $29^{\text {th }}$ day which continued till $36^{\text {th }}$ day and fell to 2 indi./ml by $40^{\text {th }}$ day. In pulse bran water, the population of $C$. reticulata started to grow from $8^{\text {th }}$ day with 1 indi./ml and became stable till $14^{\text {th }}$ day and then sudden increase to 2 individual $/ \mathrm{ml}$ by $15^{\text {th }}$ to $20^{\text {th }}$ day. After that population declined abruptly to 0 indi./ml. The number of individuals in snail faeces started to grow from $8^{\text {th }}$ day and gradually increase till $32^{\text {th }}$ day upto 3 indi. $/ \mathrm{ml}$ and then sudden increase to 14 indi./ml by $35^{\text {th }}$ day and then fell to 4 indi./ml by $39^{\text {th }}$ day. After that growth of $C$. reticulata continued with slight fluctuation from 1-3 indi./ml (Fig. 2).

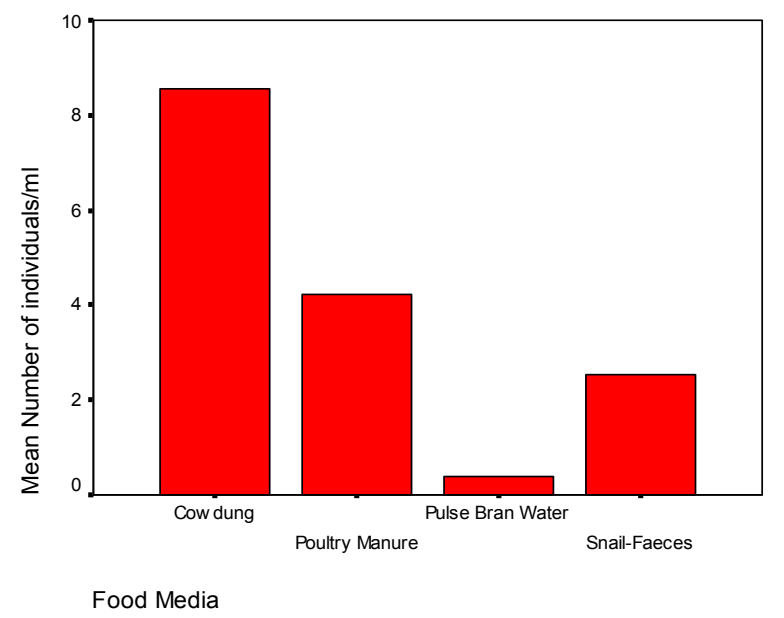

Fig.1. Average number of individuals produced in four types of feed media.

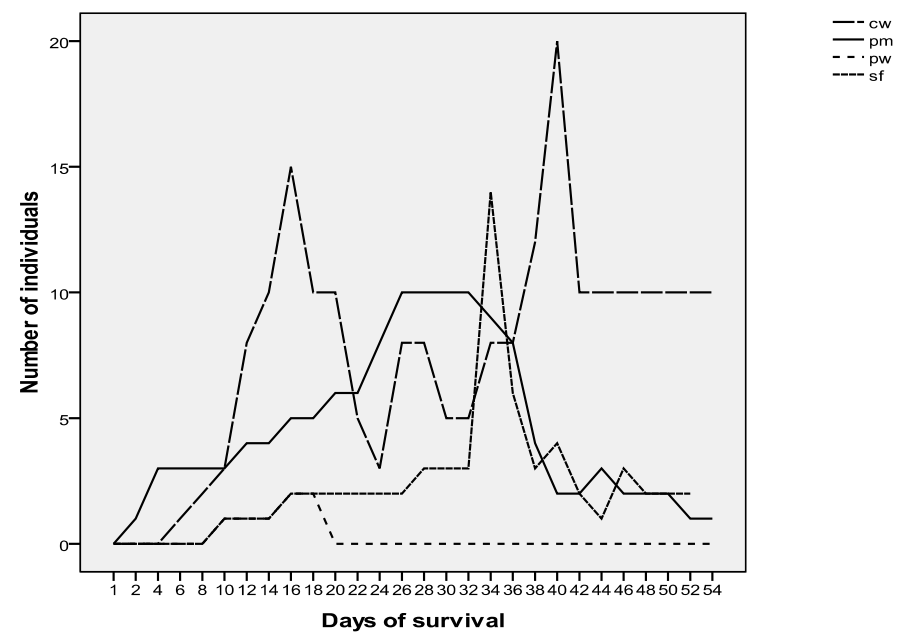

Fig. 2. Effects of days of survival on number of individuals in four types of feed media.

$*_{\mathrm{cW}}=$ cowdung, $\mathrm{pm}=$ poultry manure, $\mathrm{pw}=$ pulse water, $\mathrm{sf}=$ snail feaces. 
Effects of $\mathrm{pH}: \mathrm{pH}$ of the culture media showed profound effects on the growth of individuals which ranged from $9.1 \pm 0.40$ (snail faeces) to $7.5 \pm 0.55$ (cowdung) on an average (Table 1). It is evident that $\mathrm{pH}$ of the poultry manure indicated a significant positive relationship (0.757) with the number of individuals up to a certain range (7.410). Result showed that there were no significant differences $(p>0.05)$ between the number of individuals and $\mathrm{pH}$ of the three culture media (Table 2). Fig. 3 showed the overall effects of $\mathrm{pH}$ comparatively in four cultured media under experiment. In cowdung, number of individuals increased with increase of $\mathrm{pH}$ up to a point between 8.49.1 and then population decreased sharply with short growth phase. In poultry manure, there was some extension period of population growth with few lag phases but showed optimum abundances within $\mathrm{pH}$ 9.2-9.8. The population of culture organism showed irregular pattern of growth in pulse bran water medium with few remarkable fluctuations at $\mathrm{pH} 8.2$ to 9.4. Number of individuals showed a downward trend with the increase of $\mathrm{pH}$ values despite of two peak curves with certain $\mathrm{pH}$ level such as at $\mathrm{pH} 7.2$ and 7.7 in snail faeces.

Table 2. Correlation of number of individuals with $\mathrm{pH}$, temperature and days of survival in different culture media.

\begin{tabular}{lccc}
\hline Food levels & $\mathrm{p}^{\mathrm{H}}$ & Temperature & Days of survival \\
\hline Cowdung & -0.248 & $0.408^{*}$ & $0.441^{*}$ \\
Poultry manure & $0.757^{* *}$ & 0.286 & 0.020 \\
Pulsebran water & 0.024 & -0.042 & -0.378 \\
Snail feaces & -0.356 & -0.388 & 0.383 \\
\hline
\end{tabular}

** significant at the 0.01 level, * significant at the 0.05 level

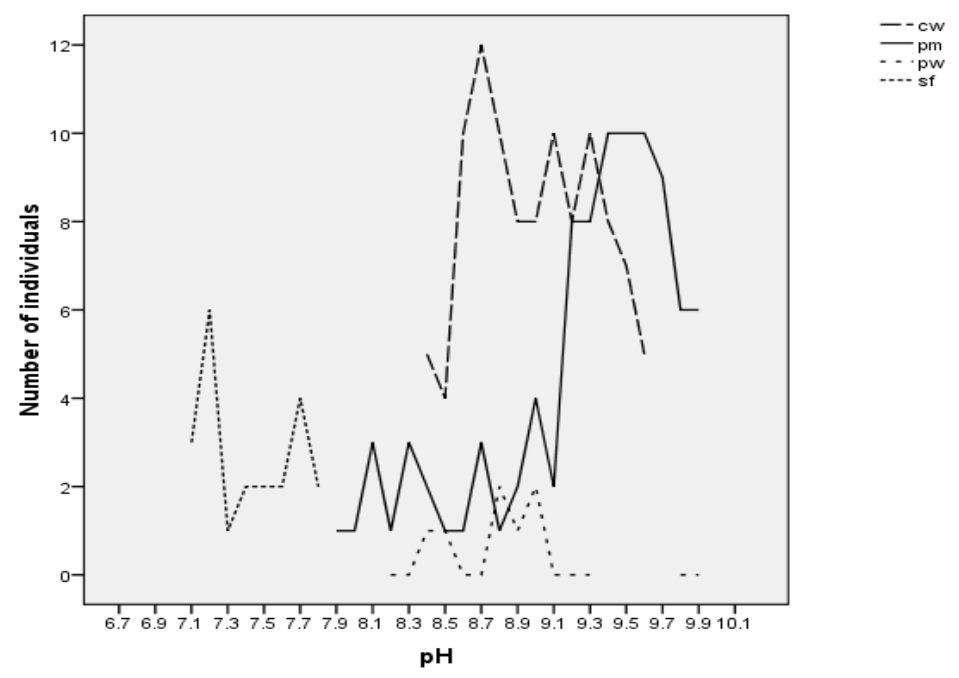

Fig. 3. Effect of $\mathrm{pH}$ on number of individuals in four types of feed media.

$* \mathrm{cw}=$ cowdung, $\mathrm{pm}=$ poultry manure, $\mathrm{pw}=$ pulse water, $\mathrm{sf}=$ snail feaces. 
Effects of Temperature: Experimental results showed that the highest mean temperature was in snail faeces $\left(30.41 \pm 0.88^{\circ} \mathrm{C}\right)$ whereas lowest in cowdung medium $(26.28 \pm$ $\left.1.88^{\circ} \mathrm{C}\right)$. The correlation between mean temperature $(0.408)$ and population density of cowdung medium shows positive relationship (Table 2).

Fig. 4 showed the comparative effects of temperature on number of individuals cultured in four types of feed media with a great variation. In cowdung, number of individuals increased with the increase of temperature following few fluctuations. The figure reached at peak sharply at $23^{\circ} \mathrm{C}, 25^{\circ} \mathrm{C}$ and $26^{\circ} \mathrm{C}$ temperature and dramatic declined at $23-24^{\circ} \mathrm{Cand}$ $25.5^{\circ} \mathrm{C}$. After a short lag phase, growth of individuals continued its upward trend till $29^{\circ} \mathrm{C}$. In poultry manure, the number of individuals increased steadily from 25 to $28^{\circ} \mathrm{C}$ and then declined abruptly at $28.5^{\circ} \mathrm{C}$. Then population increased sharply with little fluctuation within 29 to $30^{\circ} \mathrm{C}$. The number of individuals in pulse bran water medium did not increase beyond the inoculation density $(2 \mathrm{ind} . / \mathrm{ml})$ and showed temperature range between $26^{\circ} \mathrm{C}$ to $29.5^{\circ} \mathrm{C}$ with a small peak at $27^{\circ} \mathrm{C}$. The temperature recorded in snail faeces culture medium was confined between 29 to $31^{\circ} \mathrm{C}$ with a single peak at $30^{\circ} \mathrm{C}$ (Fig. 4).

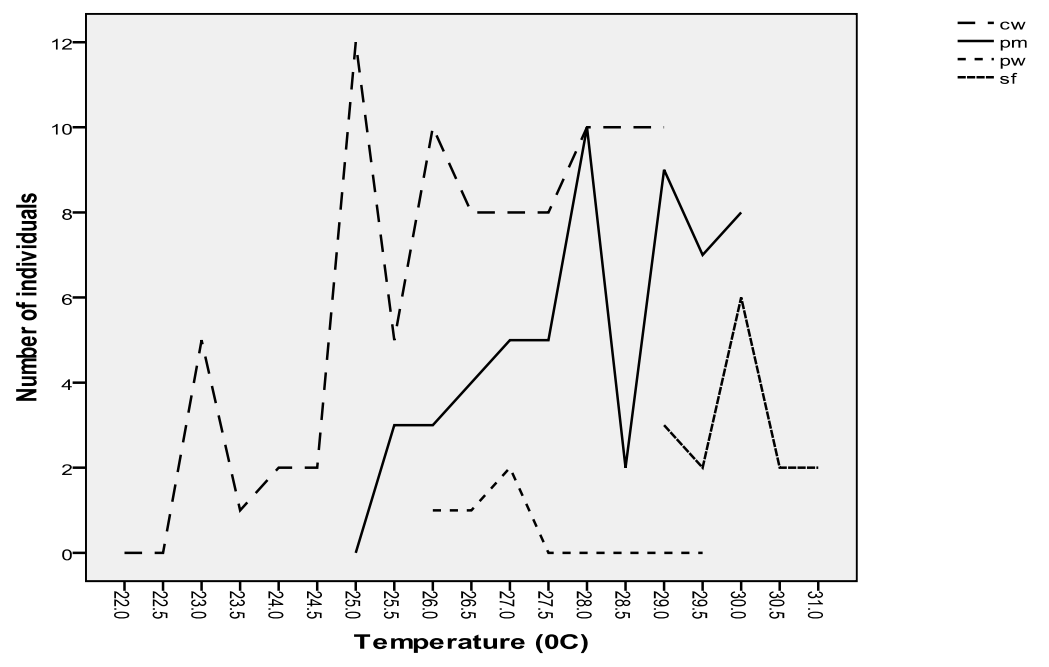

Fig.4. Effect of temperature on number of individuals in four types of feed media. $* \mathrm{cw}=$ cowdung, $\mathrm{pm}=$ poultry manure, $\mathrm{pw}=$ pulse water, $\mathrm{sf}=$ snail feaces

Table 3 depicts the simple regression analysis with $\mathrm{pH}$, water temperature and days of survival on the number of $C$. reticulata in different culture media. In cow dung media, the contribution of $\mathrm{pH}$ is inversely proportional to the production of number of individuals whereas temperature and days of survival are more contributing parameters for the production of $C$. reticulata than that of $\mathrm{pH}$ parameter. In poultry manure, $\mathrm{pH}$ and temperature are more important for the number of individuals than days of survival which is inversely proportional to the production of days of survival. Similar type of result was found in pulse bran water medium. In snail faeces, $\mathrm{pH}$ and temperature are more 
inversely proportional to the production of number of individuals and days of survival are less prominent parameter for detecting the number of $C$. reticulata.

Table 3. Regression of $\mathrm{pH}$, temperature and days of survival on number of individuals.

\begin{tabular}{l|l|l|l}
\hline Food levels & Regression line & $\mathrm{R}^{2}$ & Adjusted $\mathrm{R}^{2}$ \\
\hline Cow dung & $\begin{array}{l}\text { No. of individuals }=23.531-3.948 \mathrm{pH}+0.309 \\
0.602 \text { Temperature }+6.72 \text { Days of survival }\end{array}$ & 0.210 \\
Poultry manure & $\begin{array}{l}\text { No. of individuals }=46.21+3.49 \mathrm{pH}+0.736 \\
0.810 \text { Temperature }-0.106 \text { Days of survival }\end{array}$ & 0.704 \\
Pulse bran & $\begin{array}{l}\text { No. of individuals = - 3.39 + 0.294 pH }+0.25 \\
\text { water }\end{array}$ & 0.152 \\
Snail faeces & $\begin{array}{l}\text { No. of individuals = 31.908 - 1.05 pH -0.74 } 0.219 \\
\text { Temperature + 3.11 Days of survival }\end{array}$ & 0.081 \\
\hline
\end{tabular}

Comparison of the number of the culture organisms in four different media revealed that growth rate of $C$. reticualta was considerably good in cowdung medium, average in poultry manure and then snail faeces and pulse bran water respectively (Fig. 1). The highest growth rate (20 individuals $/ \mathrm{ml})$ was achieved in the cowdung medium might be the cause for rich nutrient component available than those of others. Muthupriya and Altaf (2009) have observed $3593 \pm 258$ to $9333 \pm 203$ individuals/litre of $C$. cornuta population in chicken manure medium which was more or less similar to the findings in present study for poultry manure (1-10 individuals $/ \mathrm{ml})$. In this medium, the peak population density was observed on the $24^{\text {th }}$ to the $34^{\text {th }}$ day which is in contradiction to the findings of Altaf and Mehraj-ud-Din (2010) who detected peak on the $17^{\text {th }}$ day. Malhotra and Langer (1993) studied on the four cladoceran species of importance as fish food organisms, viz. Daphnia similes (Claus), Simocephalus vetulus (Schodler). Moina macrocopa (Straus) and Ceriodaphnia cornuta (Sars) which were maintained in the laboratory on nutrient sources including manure, rice bran and Chlorella. The organisms responded better with rice bran and Chlorella. The findings of the present study indicate that $C$. reticulata cultured in pulse bran water medium with Chlorella inoculums had exhibited the lowest growth rate with an average $(0.37 \pm 0.69$ indi./ml $)$ that differed from the previous findings of Malhotra and Langer (1993).

Studies revealed that nutrient and temperature have significant effects on the life cycles of the planktonic species (Ebert et al. 1993, Gillooly 2000 and Savage et al. 2004) which in turn affected the population growth of zooplanktons. This was evident in C. reticualta cultured in cowdung medium up to a certain range $\left(25-29^{\circ} \mathrm{C}\right)$ of temperature. Normally under optimal range of culture conditions, the population growth rates of cladocerans are directly related to the food density and different temperature gradients (Nandini and Sarma 2003, Sarma et al. 2005, Xi et al. 2005). C. reticulata had optimal growth rates at $25^{\circ} \mathrm{C}$ in cowdung medium, $28^{\circ} \mathrm{C}$ in poultry manure, $27^{\circ} \mathrm{C}$ in pulse bran water media and $30^{\circ} \mathrm{C}$ in snail faeces medium. 
Temperature is one of the major determinants of the feeding rate of Ceriodaphnia. Gopen (1976) showed that Ceriodaphnia feed at higher rates when the water temperature increased and it occurred upto a certain level. According to Gopen (1976), the optimum temperature for C. reticulata ranged from $20-22^{\circ} \mathrm{C}$. He also opined that reproduction and growth rates of $C$. reticulata decreased at temperature above $22^{\circ} \mathrm{C}$ due to the increase in energy requirements released from increases in the respiration rates and slightly different results obtained from previous findings which support the results of Tauson (1930). He studied Daphnia pulex and observed the temperatures between 15 and $25^{\circ} \mathrm{C}$ were favourable for egg production, but above and below these temperatures; there was a considerable decline in the number of egg production. Similar effects at higher temperature have also been recorded in Ceriodaphnia sp. (Green 1978) and Moina macrocopa (Malhothra and Langer 1990). Hall (1964) stated that temperature tolerance may be utilized to predict the frequency of molting, reproduction, and duration of the egg development. Bellosillo (1937) reported that temperature ranging from $26-31^{\circ} \mathrm{C}$ to be favourable for laboratory and outdoor cultures of zooplankter, Moina macrocopa.

It is apparent that temperature alone may not account for variations in plankton densities as other parameters such as high $\mathrm{pH}$, alkalinity, carbon dioxide but nutrients are also responsible for the organic mass production (Pulle and Khan 2003). Hydrogen ion concentrations have great impact on the survival, growth and reproduction rates of cladocera (Walton et al. 1982 and Moustafa 2007). The results of the present study exhibited that $\mathrm{pH}$ recorded in the poultry manure medium have a significant effects on the growth of C. reticulata (Table 2).

C. reticualta as a live food is appeared to be the best food we can possibly feed to different adult fish, fish fry and fingerlings because they are natural and healthy. Live food gives healthier fry, more successful spawns, and better colouration than any prepared food available in the market. Hence, adequate research is needed before stepping into a large scale production of $C$. reticulata using different doses of applied food media as fertilizer and to obtain optimum growth rate and continuous production of live fish feed.

\section{References}

Alam, A. K. M. N., M. A. Islam, M. F. A. Mollah and M. S. Haque. 1987. Status of zooplankton in newly constructed ponds and their relation to some meteorological and limnological factors. Bang. J. Fish. 16(1): 83-88.

Altaf, K. and W. Mehraj-ud-Din. 2010. Culture of Ceridaphnia cornuta using chicken manure as fertilizer: Conversion of waste product into highly nutritive animal protein. Pak. J. Sci and Ind. Rch. 53(2): 89-91.

Balcer, M. D., N. L. Korda and S. I. Dodson. 1984. Zooplankton of the Great Lakes: A Guide to the Identification and Ecology of the common Crustacean species. University of Wisconsin Press. Madison, Wisconsin. pp. 58-60.

Bellosillo, G. C. 1937. The biology of M. macrocopa Straus with special reference to artificial culture. Paper presented at the 4th Phil. Science Convention, 24 February 1937. 
Boyd, C.E. and Lichktoppler, F. 1979. Water Quality Management in pond fish culture. International Centre for Aquaculture. Agriculture experimentation station Auburn University Research Development Series No. 22. Project AD/DSANG. 0039.

Brooks, J. L. 1959. Cladocera. In: Freshwater Biology.(ed.W.T. Edmondson). pp. 587-656, $2^{\text {nd }}$ Edition, Wiley, New York.

Ebert, D., L. Yampolsky and S. C. Steams. 1993. Genetics of life history in Daphnia magna 1. Heritabilities at two food levels. Heredity. 70: 335-343.

Gillooly, J. F. 2000. Effect of body size and temperature on generation time in zooplankton. $J$. Plankton Res. 22: 241-251.

Gopen, M. 1976. Temperature dependence of Food Intake, Ammonia Extraction and Respiration in Ceridaphnia cornuta (Jurine) (Lake Kinneret, Isreal). Freshwat. Biol. 6(5): 451-455.

Green, J. 1978. Growth, Size and reproduction in Daphnia (Crustacea: Daphnidae), Biol. Rev. 53: $387-426$.

Hall, D. J. 1964. An experimental approach to the dynamics of a natural population of Daphnia galeata_Mendoatae. Ecology. 45(1): 94-112.

Hossain, Md. Y., S. Jasmine, Md. A. H. Ibrahim, Z. F. Ahmed, J. Ohtomi, B. Fulanda, M. Begum, A. Mamun, M. A. H. El-Kady, Md. A. Wahab. 2007. A preliminary observation on water quality and plankton of an earthen fish pond in Bangladesh: Recommendations for future studies. Pak. Jour. of Biol. Scien. 10(6): 868-873.

Hutchinson, G. E. 1967. A treatise on Limnology .vol.2. Introduction to the Lake Biology and the Limnoplankton. John Wiley and Sons, New York: 11115pp.

Kenneth, M. M. 1990. Ecology and role of Zooplankton in the fishery of Lake Naivasha, Hydrobiol. 208(1-2):131-140.

Ludwig G. M. 1999. Zooplankton Succession and Larval Fish Culture in Freshwater Ponds, Southern Regional Aquaculture, SRAC Publication No.700.

Malhotra Y. R. and S. Langer. 1990. Biological aspects of Moina macrocopa in relation to temperature variations. J. Freshwat. Biol. 2: 111-115.

Malhotra Y. R. and S. Langer. 1993. Nutritional and density-dependent responses of some cladocera. Aquacul. Res. 24 (5) : 631-640.

Moustafa, M. H. A. 2007. Comparative study on Zooplankton community collected from different irrigated fish farms and mass culture of their dominant species. Ph.D thesis, Faculty of Science. Tanta University, $205 \mathrm{pp}$.

Muthu, M. S. 1982. Methods of culturing zooplankton. CMFRI special publication- Manual of Research Methods for Fish and Shellfish Nutrition. 8: 119-125 pp.

Muthupriya, P. and K. Altaf. 2009. Mass culture of Ceridaphnia cornuta in chicken manure fertilized medium. Journ. of Exp. Zool. Ind. 12 (1):157-158.

Nandini, S. and S.S.S. Sarma. 2003. Population growth of some genera of cladocerans (Cladocera) in relation to algal food (Chlorella vulgaris) levels. Hydrobiol. 491: 211-219.

Pulle, J. S. and A. M. Khan. 2003. Phytoplanktonic study of Isapur dam water. Eco. Environ. Cons. 9: 403-406.

Rottman, R.W.1992. Culture techniques of Moina: the Ideal Daphnia for Feeding Freshwater Fish Fry. Circular 1054, Department of Fisheries and Aquatic Sciences, Florida Cooperative Extension Service, Institute of Food and Agricultural Sciences, University of Florida.

Sarma, S. S. S. and S. Nandini, and R. D. Gulati. 2005. Life history strategies of caldocerans Ceriodaphnia cf. dubia to variation in food concentration. Hydrobiol. 542: 315-333. 
Savage, V. M., J. F. Gillooly, J. H. Brown, G. B. West and E. L. Charnov. 2004. Effects of body size and temperature on population growth. The Amer. Natur. 163: 429-441.

Sibly, R. M. and J. Hone. 2002. Population growth rate and its determinants: An overview. Philosophical Transactions of the Royal Society. London B357:1153-1170.

Tauson, A. 1930.Uber die wirkung des ausseren bedingungen auf die veranderung des geschlechts und auf die entwickling von D. pulex de geer, Roux Arch. Entw. Mech. Organ. 123: 80131.

Walton, W. E., S. M. Compton, J. D. Allan and R. E. Daniels. 1982. The effect of acid stress on survivorship and reproduction of Daphnia pulex (Crustacea: Cladocera).Can. J. Zool. 60: 573-579.

Xi, Y. L., A. Hagiwara and Y. Sakakura. 2005. Combined effects of food level and temperature on life table demography of Moina macrocopa Strauss (Cladocera). Int. Rev. Hydrobiol. 90: 546-554.

(Received revised manuscript on 22 October 2013) 